\title{
Derechos Humanos y terrorismo: el caso Bin Laden Kai Ambos* http://dx.doi.org/10.21503/lex.v9i8.399
}

* Catedrático de Derecho Penal, Derecho Procesal Penal, Derecho Comparado y Derecho Penal Internacional en la Georg-August-Universität Göttingen; juez del Tribunal Provincial (Landgericht) de Göttingen. 


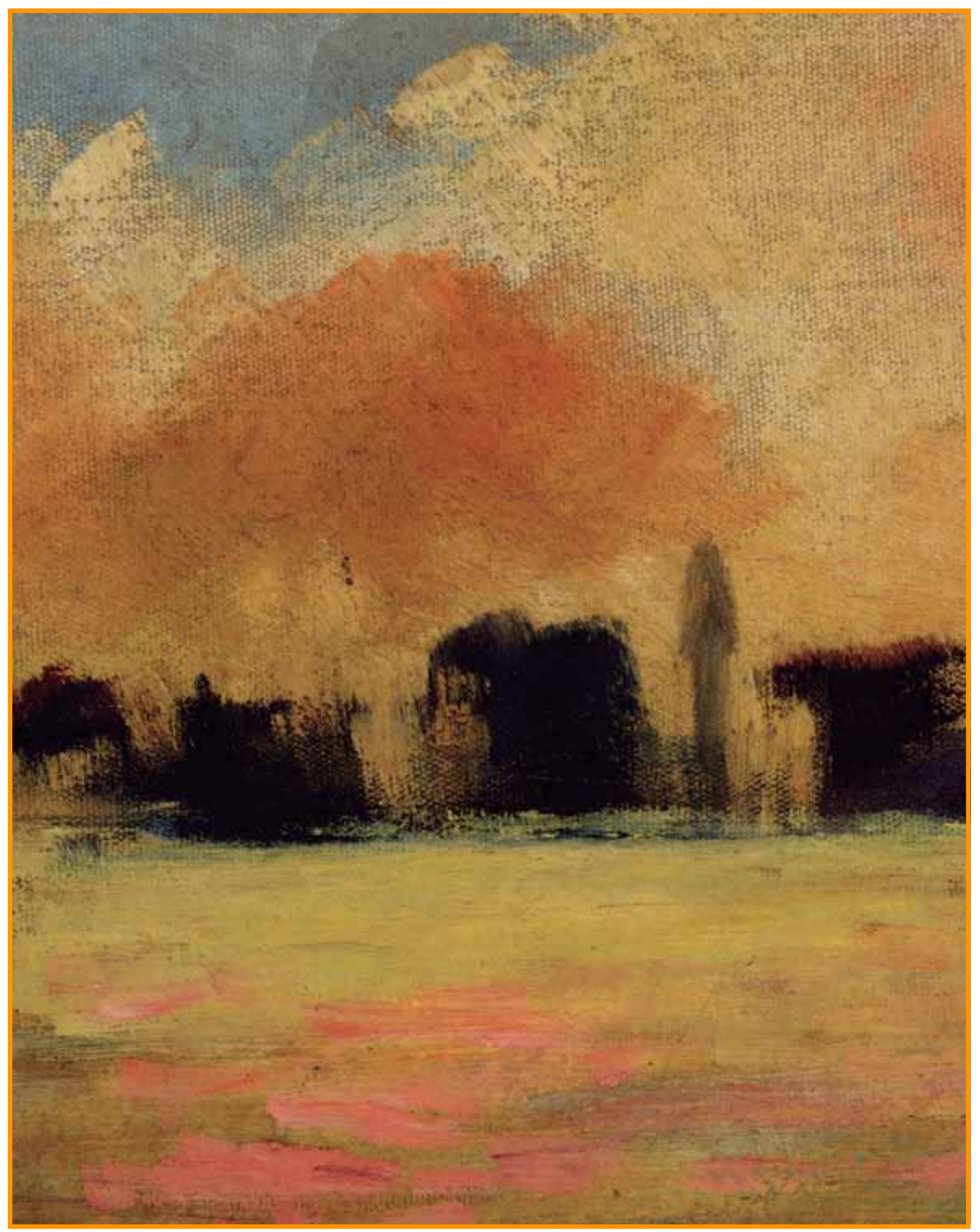

Casa lejana vaga 
I

os terroristas, también Osama Bin Laden, son humanos. Como tales, tienen Derechos Humanos. Entre ellos se encuentran el derecho a la vida, a un trato humano, y a un proceso penal justo. Los Derechos Humanos fundamentales permanecen vigentes también en un Estado de Excepción. El derecho a la vida es abrogado en tiempos de paz sólo de forma excepcional, sobre todo en casos de legítima defensa.

Si es cierto que Bin Laden se encontraba desarmado y fue selectivamente asesinado no tendría aplicación la legítima defensa, pues ella requiere una agresión actual y antijurídica sobre las fuerzas especiales que intervinieron. Teóricamente, también sería posible una errónea suposición de la situación de legítima defensa, pero el homicidio seguiría siendo objetivamente antijurídico. A diferencia de lo que piensa el presidente norteamericano, esto no sirve a la justicia, sino que más bien la perjudica.

Un Estado de Derecho trata con humanidad también a sus enemigos; captura terroristas y los lleva ante un tribunal, como la República Federal de Alemania hizo con la RAF (Fracción del Ejército Rojo) y hace actualmente con miembros de Al Qaeda. Si se establece la culpabilidad de estas personas en un debido proceso conducido ante un tribunal imparcial, ellas pueden ser condenadas a severas penas, incluso en algunos países como los EE.UU. a la pena de muerte. Un homicidio sin un proceso judicial es una ejecución extrajudicial, por la cual Estados criminales son demandados frente a organismos de Derechos Humanos.

En la guerra, es decir en un conflicto armado en el sentido del Derecho Internacional humanitario, la situación jurídica es algo distinta. Aquí se puede dar muerte a personas, siempre que tomen parte activa y directa en las hostilidades. La prohibición de matar se suspende en conflictos armados internacionales para los combatientes y en conflictos armados no internacionales para los combatientes de facto. Éstos pueden ser selectivamente asesinados si se cumplen ciertos requisitos, entre los que se destaca el respeto del principio de proporcionalidad, según el cual se deben preferir las medidas menos lesivas (arrestos) y evitar victimas civiles innecesarias.

Si esto ocurre en territorio extranjero, este Estado debe aprobar la operación; de otro modo, hay una lesión de la soberanía contraria al Derecho Internacional. En contra de ciertas 
declaraciones escuchadas en estos días, las resoluciones del Consejo de Seguridad de las Naciones Unidas sobre la lucha contra el terrorismo internacional, especialmente contra Al Qaeda (Res. 1267 de 1999 hasta Res. 1974 de 2011), no autorizan este tipo de operaciones en territorio extranjero y el arresto de sospechosos de terrorismo, y mucho menos su asesinato. De estas resoluciones, no se deriva nada más que la clásica obligación de extradición o enjuiciamiento (aut dedere aut iudicare) de sospechosos de terrorismo.

La admisibilidad del asesinato selectivo fracasa en este caso, porque los EE.UU., a pesar de la confusa retórica de la 'guerra contra el terrorismo', no se encuentran en un conflicto armado contra Al Qaeda. Una red terrorista suelta y descentralizada no reúne los requisitos de una parte en conflicto en el sentido del Derecho Internacional Humanitario. Le falta, sobre todo, una estructura de comando centralizada y jerarquizada militarmente, además del control de un determinado territorio. Si se proclama que existe un conflicto armado mundial contra $\mathrm{Al}$ Qaeda, entonces todo el globo sería un campo de batalla y la clásica comprensión de conflicto armado, como una contienda militar limitada a un territorio soberano estatal, se extiende desmesuradamente.

Si bien no se puede negar que en conflictos armados pueda haber ciertos cruces de frontera, como la retirada de una parte en conflicto en territorio soberano de un Estado vecino (como los talibanes afganos en el territorio del vecino Paquistán), la extensión extraterritorial permanecería vinculada al conflicto territorial inicial y no convertiría al mundo entero en un campo de batalla con imprevisibles consecuencias para quienes, en función de objetivos militares, son declarados sospechosos de terrorismo. En última instancia, una disputa mundial semejante arrastraría el conflicto a todos los países en los que se encuentren terroristas, aunque el Estado que conduce la ofensiva no se encuentre en guerra con ninguno de ellos. Finalmente, incluso si se aceptara un conflicto armado entre los EE.UU. y Al Qaeda, sólo las personas que directamente participan en las hostilidades podrían ser objetivos militares del ataque. Ellas deberían, por ejemplo, conducir operaciones militares, ordenarlas o planearlas en gran medida. Ellas deberían ejercitar además una permanente función de combate. Tampoco esto es seguro en el caso de Bin Laden, pues, según la opinión de muchos, en los últimos años él era tan sólo el líder espiritual de Al Qaeda sin influencia en operaciones militares concretas.

Más allá de estas complejas e intrincadas cuestiones jurídicas, se plantea una pregunta aún más fundamental: ¿niega entonces el mundo occidental los derechos a la vida y humanos a sus enemigos y los pone a merced de una indiscriminada caza militar? Plantear esta pregunta significa negarla. La superioridad política y moral de una sociedad libre y democrática radica precisamente en que trata también a sus enemigos como personas con derechos mínimos y no se pone en el mismo nivel que ellos. Por ello, no se lleva a cabo una "guerra" contra terroristas, sino que se los combate con el Derecho Penal del Estado de Derecho. Sólo así se presta un servicio a la justicia y se crea la base para la superación del injusto terrorista. 